\title{
Contents of Caffeoylquinic Acid Compounds in the Storage Roots of Sixteen Sweetpotato Genotypes and Their Potential Biological Activity
}

\author{
Howard F. Harrison, Jr. ${ }^{1}$ \\ U.S. Vegetable Laboratory, U.S. Department of Agriculture-Agricultural Research Service, 2700 \\ Savannah Highway, Charleston, SC 29414 \\ Trevor R. Mitchell \\ Chemistry Department, University of Georgia, Athens, GA 30601 \\ Joseph K. Peterson and W. Patrick Wechter \\ U.S. Vegetable Laboratory, U.S. Department of Agriculture-Agricultural Research Service, 2700 \\ Savannah Highway, Charleston, SC 29414 \\ George F. Majetich \\ Chemistry Department, University of Georgia, Athens, GA 30601

\begin{abstract}
Maurice E. Snook
Russell Research Center, U.S. Department of Agriculture-Agricultural Research Service, Athens, GA 30601
\end{abstract}

\begin{abstract}
AdDitional Index words. Ipomoea batatas, I. pandurata, Fusarium solani, bacteria, caffeic acid, chlorogenic acid, dicaffeoylquinic acid, allelopathy

Abstract. Caffeoylquinic acid compounds are widespread in plants. They protect plants against predation and infection and may have several beneficial functions in the human diet. The contents of chlorogenic acid and the 3,4-, 3,5-, and 4,5- isomers of dicaffeoylquinic acid (DCQA) in the storage root tissues of 16 sweetpotato [Ipomoea batatas (L.) Lam.] genotypes were determined. Averaged over genotypes, the contents of the four compounds were highest in the cortex, intermediate in the stele, and lowest in the periderm. Among the genotypes, chlorogenic acid contents ranged from 16 to $212 \mu \mathrm{g} \cdot \mathrm{g}^{-1}$ in periderm, from 826 to $7274 \mu \mathrm{g} \cdot \mathrm{g}^{-1}$ in cortex, and from 171 to $4326 \mu \mathrm{g} \cdot \mathrm{g}^{-1}$ in stele. The 3,5-DCQA isomer comprised over 80\% of total DCQA. In most genotypes, 3,5-DCQA and chlorogenic acid contents were similar in cortex and stele tissues, but chlorogenic acid was lower than 3,5-DCQA in periderm tissue. Among the 16 genotypes, total DCQA contents ranged from 0 to $1775 \mu \mathrm{g} \cdot \mathrm{g}^{-1}$ dry weight in periderm, from 883 to $8764 \mu \mathrm{g} \cdot \mathrm{g}^{-1}$ in cortex, and from 187 to $4768 \mu \mathrm{g} \cdot \mathrm{g}^{-1}$ in stele. The large differences found in a small germplasm collection suggest that selecting or breeding sweetpotato genotypes with high caffeoylquinic acid content is possible. The four caffeoylquinic acid compounds comprised over $3 \%$ of the dry weight of storage roots of the sweetpotato relative, bigroot morningglory [Ipomoea pandurata (L.) G.F.W. Meyer], indicating that it may be a good source for the compounds. The effect of DCQAs isolated from sweetpotato and $I$. pandurata tissue and caffeic and chlorogenic acid standards were tested in proso millet (Panicum milliaceum $\mathrm{L}$.), Fusarium solani (Sacc.) Mart., and bacterial growth bioassays. Caffeic acid, chlorogenic acid, and 3,5-DCQA were most inhibitory in millet and $F$. solani bioassays, but 3,5-DCQA was the least inhibitory compound in bacterial growth bioassays. Their activity in the bioassays suggests that the caffeoyl quinic acid compounds contribute to the allelopathic potential and resistance to root diseases of some sweetpotato clones.
\end{abstract}

Most research on the caffeoylquinic acids was reported during the past two decades. The chemical structure of these compounds are well characterized (Fig. 1). The compounds are ubiquitous in the plant kingdom (Takenaka et al., 2003), and levels vary widely in food crops (Clifford, 2000). Caffeoylquinic acids have many biological functions, and several areas of research indicate that they may be beneficial to humans. The DCQAs are strong antioxidants (Chuda et al., 1996), and their

Received for publication 26 Dec. 2007. Accepted for publication 7 May 2008. We thank Andrea Gilliard and Lance Lawrence for their excellent technical assistance.

Mention of a trademark name or proprietary product does not constitute a warranty or guarantee by the USDA nor does it imply exclusion of other products that may also be suitable.

${ }^{1}$ Corresponding author. E-mail: howard.harrison@ars.usda.gov. antioxidant potential is greater than that of tocopherol (Kimura et al., 1984; Murata et al., 1995; Robards et al., 1999). On a molecular basis, oxidative activity increases in proportion to the number of caffeoyl residues in the molecule (Murata et al., 1995). Other potential beneficial effects of caffeoylquinic acid compounds on humans that have been demonstrated in laboratory studies include anti-inflammatory activity (Peluso et al., 1995); reduced skin aging by inhibiting the enzyme, collagenase (Teramachi et al., 2005); anti-spasmodic activity (Trute et al., 1997); antihyperglycemic activity (Guan et al., 2006); suppression of melanogenesis (Shimozono et al., 1996); inhibited replication of the human immunodeficiency virus-1 (Robinson et al. 1996a, 1996b; Zhu et al., 1999); and reduction of the high cholesterol accumulation associated with ethanol consumption in rats (Wojcicki, 1978). 
<smiles>O=C(O)/C=C/c1ccc(O)c(O)c1</smiles>

\section{Caffeic acid}<smiles>O=C(/C=C/c1ccc(O)c(O)c1)O[C@H]1C[C@@](O)(C(=O)O)C[C@H](O)[C@@H]1OC(=O)/C=C/c1ccc(O)c(O)c1</smiles>

3,4-dicaffeoylquinic acid<smiles>O=C(/C=C/c1ccc(O)c(O)c1)OC1C[C@](O)(C(=O)O)C[C@H](O)[C@H]1O</smiles>

Chlorogenic acid<smiles>O=C(/C=C/c1ccc(O)c(O)c1)O[C@H]1C[C@@](O)(C(=O)O)C[C@H](O)[C@@H]1OC(=O)/C=C/c1ccc(O)c(O)c1</smiles>

4,5-dicaffeoylquinic acid<smiles>O=C(/C=C/c1ccc(O)c(O)c1)O[C@H]1C[C@](O)(C(=O)O)C[C@H](OC(=O)/C=C/c2ccc(O)c(O)c2)[C@H]1O</smiles>

3,5-dicaffeoylquinic acid

Fig. 1. Structures of caffeic acid, chlorogenic acid, and 3,4-, 3,5-, and 4,5-dicaffeoylquinic acid.

The caffeoylquinic acids are among numerous phenolic compounds found in plants that are thought to function in defense against predation and parasitism (Faulds and Williamson, 1999; Summers and Felton, 1994). The concentration of chlorogenic acid can increase drastically when plants are attacked by viruses, bacteria, fungi (Farkas and Kiraly, 1962; Frey-Wyssling and Babler, 1957; Kuć et al., 1956) nematodes, insects (Dowd and Vega, 1996), or in response to various nonbiotic stresses such as mechanical damage (Kojima and Kondo, 1985), ultraviolet radiation (Lott, 1960), and toxins such as mercuric chloride (Uritani et al., 1960). Although marked increases occur after attack, reports of direct evidence linking chlorogenic acid with pest resistance are sporadic (Ellis, 1998; Hung and Rhode, 1973; Johnson and Schaal, 1952; Knypl and Janas, 1976; Mote and Dasgupta, 1979; Nicholson and Hammerschmidt, 1992). Growth of gypsy moth (Lymantria dispar L.) larvae was slowed by 3,5DCQA at concentrations as low as $10 \mu \mathrm{g} \cdot \mathrm{g}^{-1}$; however, the cabbage looper (Trichoplusia ni Hubner) was not affected at concentrations of $100 \mu \mathrm{g} \cdot \mathrm{g}^{-1}$ (Beninger et al., 2004). The same authors demonstrated that the photosynthesis and growth of
Lemna gibba L. was reduced by 3,5DCQA at $100 \mu \mathrm{g} \cdot \mathrm{g}^{-1}$. Yeast, molds, and bacteria were inhibited by 1,3DCQA, 3,5-DCQA, and 4,5-DCQA (Zhu et al., 2004).

Sweetpotato phenolics were first isolated by Rudkin and Nelson (1947), who identified chlorogenic acid and related compounds. Caffeic acid, and the caffeoylquinic acid derivatives, chlorogenic and isochlorogenic acids, accumulated in wounded tissue or in response to infection by the black rot fungus, Ceratosystis fimbriata Ell. and Halst (Uritani and Miyano, 1955). The compounds called isochlorogenic acids are now known to be a mixture of mono, di, and tricaffeoylquinic acids. Walter and Schadel (1981) reported the contents of caffeoylquinic acid compounds in storage roots of 'Jewel' sweetpotato, which he described using the early designation chlorogenic acids $\mathrm{A}, \mathrm{B}$, and C. Approximately $78 \%$ of the chlorogenic acids were found in the skin and outer $5 \mathrm{~mm}$ of storage root tissue. Analysis of the outer 3-mm layer of sweetpotato storage roots of five cultivars indicated that phenolics comprised up to $0.92 \%$ of the fresh weight of this tissue (Son et al., 1991). The cultivars varied in phenolic content, and most of the phenolic component consisted of chlorogenic acid and other caffeoylquinic acids. Kojima and Kondo (1985) showed that 3,5-DCQA was formed enzymatically in sweetpotato from two molecules of chlorogenic acid (3-caffeoylquinic acid) producing a molecule of 3,5-DCQA and one of quinic acid. Islam et al. (2002) quantified chlorogenic acid, 3,5-DCQA, 4,5-DCQA, 3,4-DCQA, and 3,4,5-tricaffeoylquinic acid in the leaves of 1389 sweetpotato genotypes. Averaged over genotypes, the relative concentrations were as follows; 3,5-DCQA > 4,5-DCQA > chlorogenic acid > 3,4-DCQA > 3,4,5-tricaffeoylquinic acid. The contents of these compounds varied greatly among genotypes; for example, 3,5-DCQA contents ranged between 953 and $3503 \mathrm{mg} / 100 \mathrm{~g}$ leaf dry weight.

Rhizopus soft rot caused by the fungus Rhizopus stolonifer (Ehrenb.:Fr) Vuill. is one of the most serious postharvest diseases of sweetpotato (Clark and Moyer, 1988). This phytopathogen requires wounds that penetrate the outer layer of the storage root to cause infection. A bioassay that measured $R$. stolonifer growth revealed that 3,5-DCQA was the most inhibitory component $\left(\mathrm{EC}_{50}=2.2 \mathrm{~g} \cdot \mathrm{L}^{-1}\right)$ in an extract of the outer tissues of 'Beauregard' sweetpotato storage roots (Stange et al., 2001). Concentrations were greatest in cortex tissue, indicating that 3,5 -DCQA contributes to defense against 
infection provided by the outer layer of sweetpotato storage roots. Padda and Picha (2007a) determined the antioxidant activity and phenolic content of 'Beauregard' leaves and storage roots. The highest phenolic contents were found in young leaves where 3,5-DCQA and 3,4-DCQA were present at almost $3000 \mathrm{mg} / 100 \mathrm{~g}$ tissue dry weight. Phenolic contents in very small storage roots were also relatively high; however, contents in marketable sized sweetpotato storage roots were much lower $(<90 \mathrm{mg} / 100 \mathrm{~g})$.

During investigations of allelopathic potential and pest resistance in sweetpotato, we observed that contents of storage root phenolic compounds varied considerably among sweetpotato genotypes. The primary objective of this study was to assess the variability in the contents of chlorogenic acid and three DCQA isomers in the three tissues of storage roots of 16 sweetpotato clones. Second, DCQAs isolated from sweetpotato and I. pandurata were tested in bacterial, fungal, and seedling growth bioassays to assess their possible contribution to resistance to root rotting and allelopathy.

\section{Materials and Methods}

Sweetpotato culture and tissue preparation. Sweetpotatoes were grown using standard cultural practices (Steinbauer and Kushman, 1971) at the U.S. Vegetable Laboratory research farm at Charleston, $\mathrm{SC}$, in 2005. The soil was a Yonges silty sand (fine loamy, mixed, active, thermic Typic Endoaqualfs) with less than $1 \%$ organic matter and a $\mathrm{pH}$ of 6.5 . The 16 clones included in the study were selected for their diverse backgrounds and physical traits in hopes of obtaining genetic diversity. They included U.S. cultivars (Beauregard, Carolina Bunch, Excel, Jewel, Regal, and Sumor), U.S. Vegetable Laboratory advanced breeding clones (SC 1149-19, W-274, and W-311), cultivars from the International Institute for Tropical Agriculture in Ibadan, Nigeria (TIS 80/637, TIS 9101, and TIS 70357), accessions from the U.S. Plant Introduction Collection [PI 399163, PI 153655 (Tinian), and PI 634402 (Sulfur)], and a Brazilian cultivar (Simon). Ten plant plots of each clone were grown in a randomized block design with four replications. At approximately $120 \mathrm{~d}$ after planting, freshly hand-harvested (uncured) sweetpotato storage roots that were free of rotting, severe insect damage, and physical injury were gently scrubbed with a soft brush under running water, and periderm tissue was removed by scraping with a scalpel. Periderm-free storage roots were sliced into discs and separated into cortex and stele tissues. Tissue samples were freeze dried and then finely ground under liquid nitrogen using a mortar and pestle, dried at $55^{\circ} \mathrm{C}$ for approximately $12 \mathrm{~h}$, and stored under nitrogen at $-20{ }^{\circ} \mathrm{C}$ until extracted. A storage root (approximately $5 \mathrm{~cm}$ diameter) was collected from an $I$. pandurata (also called bigroot morningglory and wild sweetpotato) plant growing in an undisturbed area at the U.S. Vegetable Laboratory and was processed like the sweetpotatoes.

QUANTIFICATION OF CAFFEOYL QUINIC ACID COMPOUNDS. Freeze-dried samples $(\approx 200 \mathrm{mg}$ ) of the stele, cortex, and periderm from the sweetpotato clones and I. pandurata were extracted with $2 \mathrm{~mL}$ of $\mathrm{MeOH}$ containing $0.12 \mathrm{mg} \cdot \mathrm{mL}^{-1}$ of chrysin (Sigma-Aldrich, St. Louis, MO), recrystallized from amyl alcohol, as an internal standard. The samples were placed in an ultrasonic bath for $30 \mathrm{~min}$ and then filtered through 0.45 $\mu \mathrm{m}$ nylon filters. The samples were analyzed using a highperformance liquid chromatography (HPLC; model 1050;
Hewlett Packard, Atlanta) apparatus with an Ultrasphere C-18, $5-\mu \mathrm{m}, 4.6 \times 250 \mathrm{~mm}$ column (Beckman Coulter, Fullerton, $\mathrm{CA})$. The solvent gradient was linear from $10 \% \mathrm{MeOH}$ to $100 \%$ $\mathrm{MeOH}$ over $35 \mathrm{~min}$, the flow rate was $1 \mathrm{~mL} \cdot \mathrm{min}^{-1}$, and $0.1 \%$ phosphoric acid was included in both solvents. Column eluent was monitored at $340 \mathrm{~nm}$. Peaks were identified and quantified by comparing retention time and peak areas to those of standard compounds. Caffeic acid and chlorogenic acid standards were purchase from Sigma-Aldrich and the three isomers of DCQA were isolated as described below. Figure 2 shows typical chromatograms for caffeoylquinic compounds from I. pandurata stele and 'Jewel' cortex.

ISOLATION OF DCQA FOR BIOASSAY AND IDENTIFICATION. Ipomoea pandurata stele was the source of 3,4-DCQA and 4,5-DCQA. Freeze-dried stele (30 g) was extracted three times with $500 \mathrm{~mL}$ of $\mathrm{MeOH}$ and the combined extracts were reduced in volume to approximately $200 \mathrm{~mL}$ then $50 \mathrm{~mL}$ of water was added and the remaining $\mathrm{MeOH}$ was removed by rotary evaporation. The aqueous solution was separated by preparative C-18 column chromatography. Preparative bulk C-18 (100 g; Waters, Milbury, MA) was slurry packed in $\mathrm{MeOH}$ into a glass chromatography column, washed with $\mathrm{MeOH}$, and recycled to water. The sample was applied to the top of the column and was eluted with varying percentages of $\mathrm{MeOH} /$ water. Nitrogen pressure at approximately $69 \mathrm{kPa}$ aided flow. The DCQAs eluted with $25 \%$ to $50 \% \mathrm{MeOH}$. Individual isomers were separated by stepwise, gradient elution with $\mathrm{MeOH} /$ water on the Waters Preparative bulk C-18. Fractions were monitored by HPLC and fractions containing the same isomers were combined. Individual isomers were purified by silicic acid (100 mesh; Mallinckrodt, Hazelwood, MO) column chromatography with $\mathrm{CH}_{2} \mathrm{Cl}_{2}$, EtOAc, acetone, and EtOH mixtures. PI 399163 cortex was the source for 3,5-DCQA. It was extracted with $\mathrm{MeOH}$ and concentrated as described above. The aqueous solution was saturated with $\mathrm{NaCl}$ and extracted with three times with $50 \mathrm{~mL}$ of EtOAc, and the EtOAc was dried with anhydrous $\mathrm{Na}_{2} \mathrm{SO}_{4}$. The EtOAc solution was deposited onto silicic acid and chromatographed as above. The individual isomers were submitted to HPLC-mass spectrometry (MS) using a ThermoQuest Finnigan LCQ Duo (ESI) (Thermo Fisher Scientific, Waltham, MA). Samples were injected using a Spectra System AS 3000 auto injector (Spectra Systems, Providence, RI), and a Spectra System P2000 was used to pump the mobile phase at $0.2 \mathrm{~mL} \cdot \mathrm{min}^{-1}$. The same HPLC column used for the quantitative analysis was used for the MS runs with a methanol/water gradient beginning at $10 \%$ methanol, and increasing to $100 \%$ over $35 \mathrm{~min}$. Both solvents contained formic acid at $0.1 \%$. Elution was monitored at $340 \mathrm{~nm}$ using a Spectra System UV 6000LP connected in series with the MS. Isomers were identified by comparing HPLC elution order (Islam et al., 2002), and HPLC/MS ${ }^{2}$ fragmentation patterns (Table 1) to those reported in the literature (Clifford et al., 2005).

Proso millet Seed germination bionssay. Test compounds were dissolved in $0.5 \mathrm{~mL}$ of $\mathrm{MeOH}$ and were pipetted into 35$\mathrm{mm}$ disposable petri dishes containing a filter paper. Controls received $0.5 \mathrm{~mL}$ of $\mathrm{MeOH}$ only. $\mathrm{MeOH}$ was allowed to evaporate and $0.5 \mathrm{~mL}$ of water was added to each dish. Test concentrations were 0,5 , and $10 \mathrm{~mm}$ for each compound. Ten proso millet seeds were added to each dish, and all were incubated in the dark at $22.5^{\circ} \mathrm{C}$ for $72 \mathrm{~h}$. Radicle lengths were measured with an electronic caliper. The experiment was arranged in a completely random design with five replication and was repeated. 

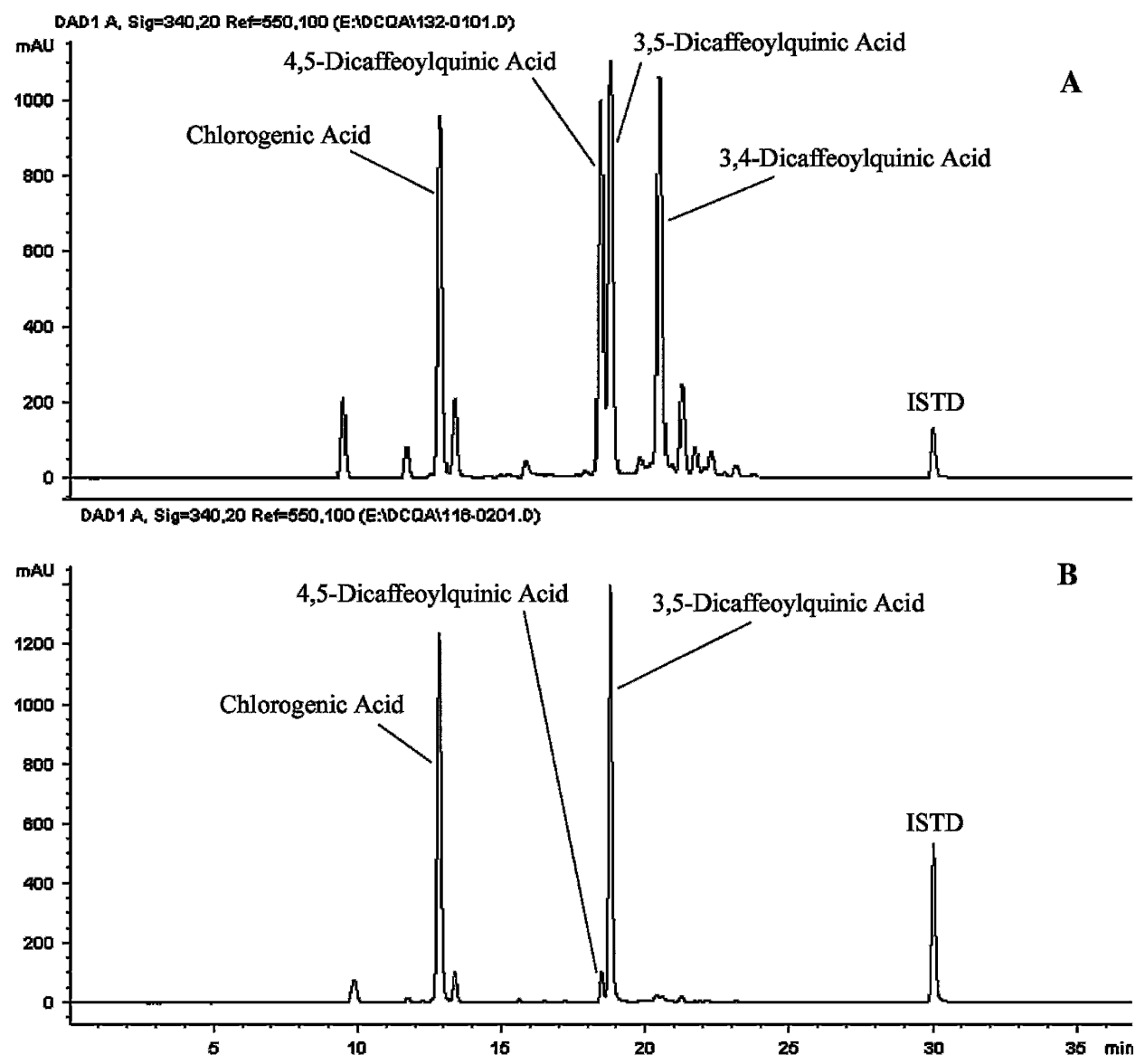

Fig. 2. Comparison of high-performance liquid chromatograms of caffeoylquinic acid compounds from Ipomea pandurata stele (A) and I. batatas 'Jewel' cortex (B).

Fusarium Solani bioassay. Phenolics were pipetted into 35-mm disposable petri dishes in $0.5-\mathrm{mL} \mathrm{MeOH}$ aliquots, and the $\mathrm{MeOH}$ was evaporated in a transfer hood. Control dishes received $0.5 \mathrm{~mL}$ of $\mathrm{MeOH}$ without phenolics. Test concentrations were 0,5 , and $10 \mathrm{~mm}$ for each compound. A $1.0-\mathrm{mL}$ aliquot of hot potato dextrose agar medium (PDA) was added to each dish and was allowed to gel in a transfer hood. A small $(<1 \mathrm{~mm})$ piece of $F$. solani mycelium from an actively growing PDA culture was transferred to the center of each dish. The dishes were sealed in plastic food containers and incubated at $25^{\circ} \mathrm{C}$ for $60 \mathrm{~h}$. The diameter of the colony on each dish was measured with an electronic caliper and converted to area. The experiment was arranged in a completely random design with five replications and was repeated.

BaCtERIAL BIOASSAY. The eight bacterial isolates used in the bacterial inhibition study are listed in Table 2. Bacteria were grown on pseudomonas agar F (MP Biomedicals, Solon, OH) overnight at $28^{\circ} \mathrm{C}$, with the exception of the Ralstonia solanacearum Yabuuchi et al. isolate, which was grown on Difco ${ }^{\mathrm{TM}}$ tryptic soy agar (Becton Dickinson, Sparks, MD). Test compounds were dissolved in methanol to final concentrations of $1000,100,10$, and $1 \mu \mathrm{g} \cdot \mathrm{mL}^{-1}$. Assays were performed by pipetting $100 \mu \mathrm{L}$ of a methanol solution containing the test compounds into wells of 96-well Falcon ${ }^{\circledR}$ Microtest $^{\mathrm{TM}}$ tissue culture plates (Becton Dickinson Labware, Franklin Lakes, NJ). Control wells received $100 \mu \mathrm{L}$ of pure methanol. Plates were left open in a sterile, laminarflow bench until the methanol was completely evaporated. King B broth (King et al., 1954) $(100 \mu \mathrm{L})$ was added to all wells. Bacteria were scraped from the overnight plates and were resuspended and diluted in sterile phosphate-buffered saline to an optical density 0.1 at $600_{\mathrm{nm}}$. Each well was inoculated with $10 \mu \mathrm{L}$ of the appropriate, diluted bacterial isolate. All eight bacterial isolates were run on a single plate, and each treatment was replicated twice with an adjacent control well for comparison. Plates were covered and placed on a rotary shaker at $75 \mathrm{rpm}$ in an incubator at $28{ }^{\circ} \mathrm{C}$ for $24 \mathrm{~h}$. After $24 \mathrm{~h}$ of growth, the optical density of each well was measured at $600 \mathrm{~nm}$. The experiment was repeated twice. Optical densities were converted to a 0 to 3 rating scale as follows: $0=0 D 600_{\mathrm{nm}}$ $<0.05,1=\mathrm{OD} 600_{\mathrm{nm}} 0.06$ to $0.75,2=\mathrm{OD} 600_{\mathrm{nm}} 0.76$ to $2.0,3=$ OD $600_{\mathrm{nm}}>2.1$.

Statistical analyses. The contents of caffeoyl quinic acid compounds from the field experiment were subjected to analysis of variance using a randomized complete block design, and means for each compound within tissues were separated using the least significant difference test at $P \leq 0.05$. Data from two repetitions of the proso millet and $F$. solani bioassays were combined and subjected to analysis of variance using a completely random design, and means were separated using Duncan's multiple range test at $P \leq 0.05$. Bacterial growth ratings for the controls and the $1000 \mu \mathrm{g} \cdot \mathrm{mL}^{-1}$ treatment from two repetitions of the experiment were combined, and means and standard errors of the means were determined.

Table 1. Mass spectrometry $\left(\mathrm{MS}^{2}\right)$ fragmentation ions produced from dicaffeoylquinic acids (DCQAs) isolated from Ipomoea batatas and I. pandurata.

\begin{tabular}{|c|c|c|c|c|c|c|c|c|c|c|}
\hline$\overline{\text { Compound }}$ & Precuror ion & $\mathrm{MS}^{2}$ base peak & & & & MS & $\mathrm{ons}^{\mathrm{z}}$ & & & \\
\hline 3,4-DCQA (m/z) & 514.9 & 352.9 & $334.9^{2}$ & $316.8^{3}$ & $298.8^{13}$ & $255.0^{8}$ & $203.0^{14}$ & $191.0^{1}$ & $179.0^{7}$ & $172.9^{5}$ \\
\hline $3,5-\mathrm{DCQA}(\mathrm{m} / \mathrm{z})$ & 515.0 & 352.9 & $334.9^{1}$ & - & - & - & $203.0^{1}$ & $191.0^{3}$ & $178.9^{4}$ & $173.0^{1}$ \\
\hline $4,5-\mathrm{DCQA}(\mathrm{m} / \mathrm{z})$ & 515.0 & 352.9 & $335.0^{11}$ & $316.8^{1}$ & $298.8^{5}$ & $255.0^{3}$ & $203.0^{6}$ & $191.0^{4}$ & $178.9^{14}$ & $173.0^{2}$ \\
\hline
\end{tabular}

${ }^{\mathrm{z}}$ Superscripted numbers are the relative intensities of the ions. 
Table 2. Bacteria included in bioassay experiments to determine the activity of caffeic acid, chlorogenic acid, and three isomers of dicaffeoylquinic acid.

\begin{tabular}{lll}
\hline Species & \multicolumn{1}{c}{ Relevant characteristics } & Reference \\
\hline Acidovorax avenae & Subspecies citrulli (phytopathogen) & R. Walcott, unpublished \\
Erwinia chrysanthemi & From sweetpotato (phytopathogen) & This study \\
Pseudomonas putida & RCB1 (Rhizosphere colonizer: nonpathogen) & This study \\
Pseudomonas synxantha & BG33R (biological control of nematodes) & Wechter et al., 2001 \\
Pseudomonas syringae & Pathovar maculicola (phytopathogen) & Wechter et al., 2006 \\
Pseudomonas syringae & Pathovar tomato (phytopathogen) & This study \\
Ralstonia solanacearum & Race1, Biovar 1 SC14 (phytopathogen) & Robertson et al., 2004 \\
Xanthomonas campestris & Pathovar campestris (phytopathogen) & This study \\
\hline
\end{tabular}

\section{Results and Discussion}

Storage root Contents of CAFFEOYlquiniC ACIDS. Average chlorogenic acid contents for the 16 sweetpotato clones were 60,2423 , and $1099 \mu \mathrm{g} \cdot \mathrm{g}^{-1}$ in periderm, cortex, and stele tissue, respectively (Table 3 ). Contents ranged from 16 to $213 \mu \mathrm{g} \cdot \mathrm{g}^{-1}$ in periderm tissue, 852 to $7274 \mu \mathrm{g} \cdot \mathrm{g}^{-1}$ in cortex tissue, and 317 to $7435 \mu \mathrm{g} \mathrm{g}^{-1}$ in stele tissue. Average total DCQA contents for the 16 sweetpotato clones were 90,511 , and $37 \mu \mathrm{g} \cdot \mathrm{g}^{-1}$ for 4,5-DCQA, 3,5-DCQA, and 3,4-DCQA, respectively, in periderm tissue; 300, 2571, and $28 \mu \mathrm{g} \cdot \mathrm{g}^{-1}$ for 4,5-DCQA, 3,5DCQA, and 3,4-DCQA, respectively, in cortex tissue; and 76, 893, and $12 \mu \mathrm{g} \cdot \mathrm{g}^{-1}$ for 4,5-DCQA, 3,5-DCQA, and 3,4-DCQA, respectively, in stele tissue. Total DCQA contents ranged from 0 to $1775 \mu \mathrm{g} \cdot \mathrm{g}^{-1}$ in periderm tissue, 883 to $8764 \mu \mathrm{g} \cdot \mathrm{g}^{-1}$ in cortex tissue, and 187 and $4768 \mu \mathrm{g} \cdot \mathrm{g}^{-1}$ in stele tissue. Chlorogenic acid and 3,5-DCQA were present at similar levels in the cortex and stele tissues of most cultivars. As observed in previous experiments (Peterson et al., 2005), chlorogenic acid contents were very low in periderm tissue. Averaged over clones, the 3,5 -DCQA isomer comprised over $80 \%$ of the total cortex and stele DCQA content, and 4,5-DCQA contents were 10 times greater than 3,4-DCQA contents in cortex tissue and three times greater than 3,4-DCQA contents in stele tissue. Interestingly, the U.S. commercial cultivars included in the study were relatively low in these compounds. Because chlorogenic acid is responsible for discoloration after wounding, cooking, or exposure to ferrous ion (Walter and Schadel, 1981), breeders may have inadvertently developed low-content cultivars by selecting against discoloration.

Variability in contents of caffeoylquinic acid compounds within clones was relatively high as indicated by the large LSDs; however, an external stimulus for this variation was not apparent. Although the field planting was arranged in a replicated block design, and blocks were harvested and processed sequentially, block effects were insignificant for all analyses of variance. Padda and Picha (2007a) reported that very small 'Beauregard' storage roots (average diameter = $1.2 \mathrm{~cm}$ ) were higher in caffeoylquinic acid compounds than were larger roots. The marketable-sized roots harvested for our study were in the larger two categories they described, and contents in the larger roots were similar to those we observed. The variability encountered in this study indicates that a relatively high level of replication may be needed to accurately estimate contents in sweetpotato storage roots. A better understanding of the factors that influence accumulation would also be helpful in designing experiments.

Storage root caffeic acid contents were also determined (data not presented). Average periderm caffeic acid contents ranged between 0 and $102 \mu \mathrm{g} \cdot \mathrm{g}^{-1}$, cortex contents ranged between 0 and $5 \mu \mathrm{g} \cdot \mathrm{g}^{-1}$, and stele contents ranged between 0 and $24 \mu \mathrm{g} \cdot \mathrm{g}^{-1}$. In previous studies (Harrison et al., 2003, 2006), the caffeic acid content of cortex and stele tissue was consistently very low; however, caffeic acid contents of greater than $5.0 \mathrm{mg} \cdot \mathrm{g}^{-1}$ were observed in periderm tissue in some clones. We (Harrison et al., 2006) demonstrated that caffeic acid content in storage root periderm from greenhouse-grown sweetpotato plants that were subjected to drought stress were much higher than in periderm from plants that were not stressed. Periderm caffeic acid contents averaged $65 \mu \mathrm{g} \cdot \mathrm{g}^{-1}$ in nonstressed plants and $1562 \mu \mathrm{g} \cdot \mathrm{g}^{-1}$ in stressed plants. The similarity of the periderm caffeic acid contents in this experiment with those of the nonstressed plants from the greenhouse study suggests that environmental factors, possibly moisture stress, that stimulate the accumulation of periderm caffeic acid were not present in this study.

Chlorogenic acid and the three isomers of DCQA comprised over $3 \%$ of the dry weight of the stele tissue of I. pandurata. Unlike the sweetpotato clones, contents of the three isomers of DCQA in I. pandurata were similar and roughly equal to the chlorogenic acid content. The species is native from Florida to Texas and northward to southern Canada (Horak and Wax, 1991), and its storage roots can reach dimensions greater than $10 \mathrm{~cm}$ in diameter and $2 \mathrm{~m}$ in length and obtain a mass over $30 \mathrm{~kg}$. Due to its widespread adaptation and high storage root production, I. pandurata may be useful as a source for the dicaffeoylquinic acids.

Bionssays. Previous studies demonstrated that caffeic and chlorogenic acids are highly inhibitory in plant and fungal growth bioassays (Harrison et al., 2003; Peterson et al., 2005). They were included in these experiments to provide a reference for the activity of the DCQAs that had not previously been tested in these bioassays. Limited quantities of the DCQAs were available for testing. Thus, the range of concentrations tested and the degree of replication were limited.

The 5 and $10 \mathrm{~mm}$ concentrations were selected based on the activity of caffeic and chlorogenic acids in earlier studies (Harrison et al., 2003; Peterson et al., 2005). Proso millet radicle growth was inhibited by both concentrations of caffeic acid, chlorogenic acid, and 3,5-DCQA, whereas 3,4-DCQA and 4,5-DCQA did not inhibit radicle growth (Fig. 3). The activity of 3,5-DCQA in this bioassay indicates that it may contribute to the allelopathic potential of sweetpotato. Periderm levels may be most important for this activity because this tissue forms the outer layer and is continuously sloughed off during root growth. The periderm sloughing provides a mechanism for delivering defense compounds to the sweetpotato rhizosphere. Because periderm resin glycosides and caffeic acid are found at much 


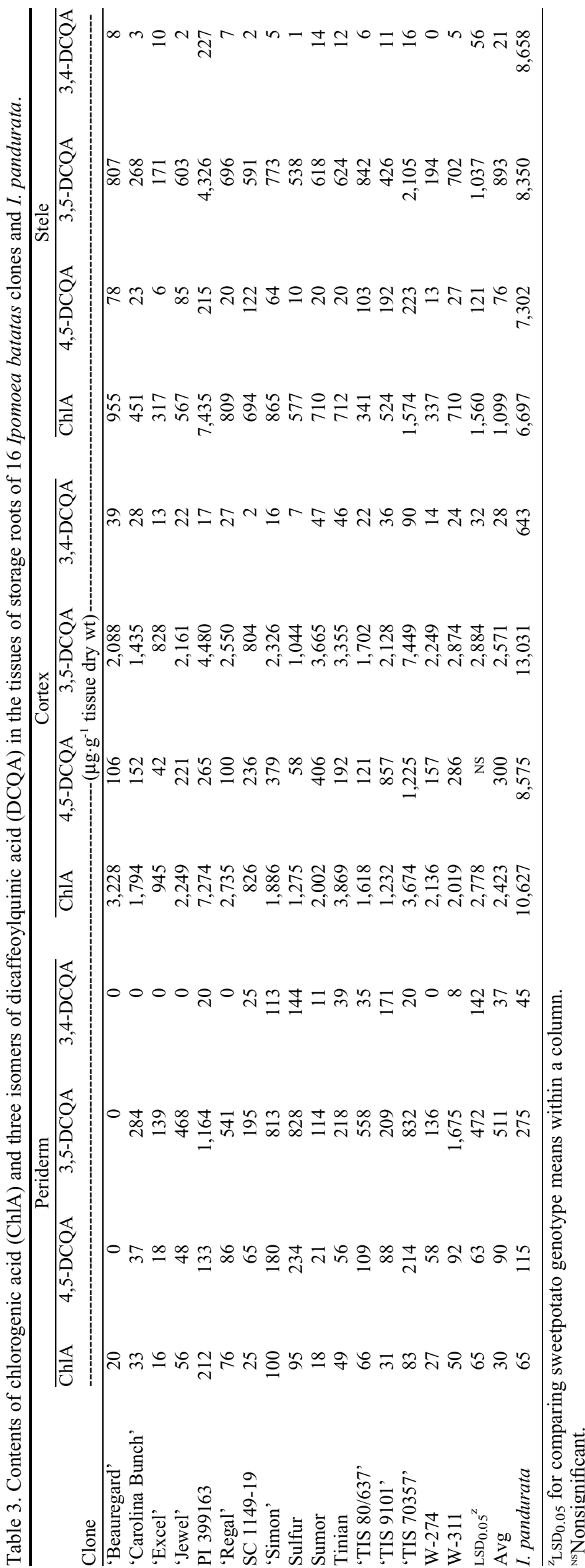

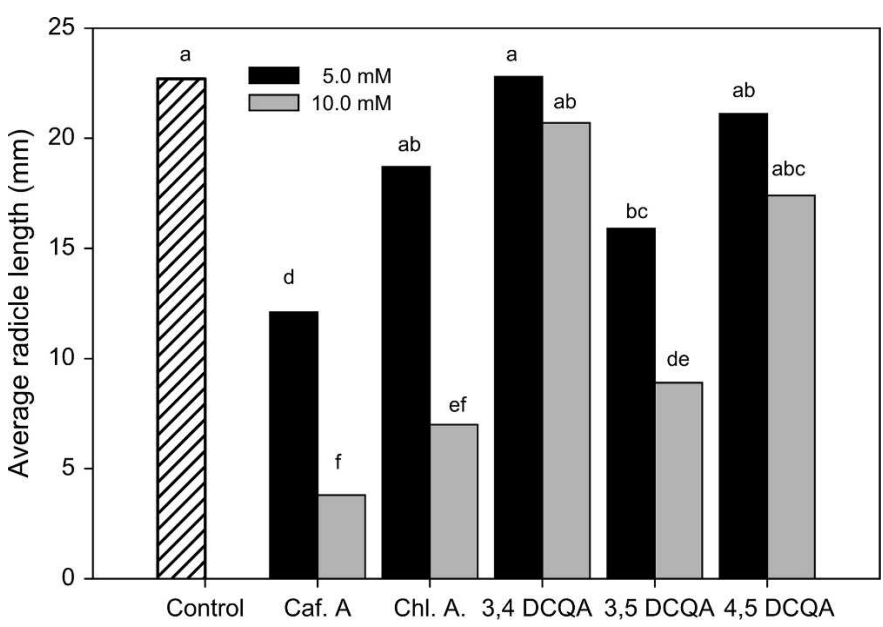

Fig. 3. Effect of caffeic acid (Caf. A.), chlorogenic acid (Chl. A.), and three isomers of dicaffeoylquinic acid (DCQA) at 5.0 and $10.0 \mathrm{~mm}$ on proso millet radicle growth in a bioassay. Means with the same letter are not different by Duncan's multiple range test at $P \leq 0.05$.

higher levels in the periderm than is 3,5-DCQA (Harrison et al., 2003 , 2005), they are probably more important allelopathic inhibitors.

The relative activity of the compounds in the $F$. solani bioassay was chlorogenic acid $>$ caffeic acid $>3,5$-DCQA $>$ 4,5-DCQA, and 3,4-DCQA did not inhibit fungal growth (Fig. 4). The inhibition of $F$. solani by chlorogenic acid and 3,5-DCQA at concentrations similar to those found in storage roots of some clones suggest that they may function in the defense against root invading fungi. The 3,5-DCQA isomer was found to be the most active inhibitor of another sweetpotato root rotting fungus, Rizopus stolonifer in 'Beauregard' storage roots (Stange et al., 2001).

In the bacterial inhibition assays, phytopathogens as well as biological control bacteria were used to determine if the reported broad-spectrum inhibition of these compounds would also be somewhat selective toward a pathogen verses a

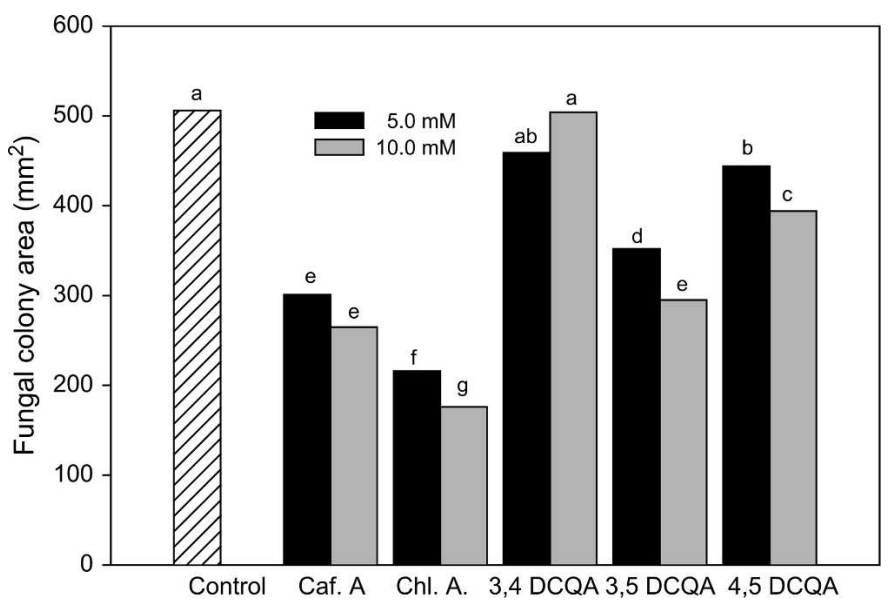

Fig. 4. Effect of caffeic acid (Caf. A.), chlorogenic acid (Chl. A.), and three isomers of dicaffeoylquinic acid (DCQA) at 5.0 and $10.0 \mathrm{~mm}$ on Fusarium solani mycelium growth in a bioassay. Means with the same letter are not different by Duncan's multiple range test at $P \leq 0.05$. 
nonpathogenic bacterium. Although four concentrations of each compound were tested against each bacterial isolate, only the highest concentration $\left(1000 \mu \mathrm{g} \cdot \mathrm{mL}^{-1}\right)$ was found to be inhibitory. All caffeoylquinic acid compounds were found to inhibit bacterial cell growth (Table 4), but 3,5-DCQA was least inhibitory. Caffeic acid did not inhibit bacterial growth. We suspect that its lack of activity in this bioassay may be due to its lower water solubility in comparison to the caffeoyl quinic acid compounds. The compound 3,4-DCQA inhibited cell growth of four phytopathogenic bacteria, Acidovorax avenae ssp. citrulli (Schaad et al.) Willens et al., Pseudomonas syringae pv. tomato (Okabe) Young, Dye \& Wilkie, R. solanacearum, and Xanthomonas campestris pv. campestris (Pammel) Dowson. Chlorogenic acid inhibited cell growth of two phytopathogenic bacteria, $P$. syringae pv. tomato and the sweetpotato pathogen Erwinia chrysanthemi Burkholder et al. Only E. chrysanthemi was inhibited by 4,5-DCQA. It is interesting to note that neither of the nonpathogenic pseudomonads, Pseudomonas synxantha (Ehrenberg) Holland or Pseudomonas putida Trevian was inhibited by any of the compounds. Surprisingly, although the pathogenic pseudomonads, $P$. syringae pv. tomato and $P$. syringae pv. maculicola van Hall, are closely related at the genetic and physiological level to the nonpathogenic pseudomonads (Cuppels and Ainsworth, 1995; Hendson et al., 1992), they were inhibited to some extent. Erwinia chrysanthemi, the only true bacterial sweetpotato pathogen included was moderately inhibited by all compounds except caffeic acid and 3,4-DCQA.

The large differences in the contents of caffeoylquinic acid compounds among the clones in this study indicate that breeding or selecting sweetpotato cultivars with high storage root levels of chlorogenic acid and 3,5-DCQA is possible. Due to the many human health benefits attributed to the compounds, this may be a worthwhile objective. Further study is needed to determine the heritability and stability of their contents in different environments to select the best approach. The function of the caffeoylquinic acid compounds in sweetpotato also merits further investigation. The preliminary bioassay results reported here suggest that they may contribute directly to sweetpotato allelopathy and defense against pathogens. The high caffeoylquinic acid contents in the stele of some genotypes may provide protection against pathogens that enter through wounds that penetrated the outer tissues. The caffeoyl quinic acids are more soluble than free caffeic acid and probably translocate more rapidly. Additionally, caffeic acid can be toxic to plants. The caffeoyl quinic acids may serve as a less toxic storage form for caffeic acid that can be released enzymatically. Caffeic acid accumulates at high levels in the periderm under some conditions (Harrison et al., 2003), but is found only at very low concentrations in the inner tissues. If the compounds are proven to impart resistance to rotting, then their content in sweetpotato may serve as a marker for pest resistance. Recent reports by Padda and Picha (2007b) and Truong et al. (2007) optimized HPLC quantification of sweetpotato phenolics using isocratic programs that required shorter elution time than ours. Their methodologies may be superior for large-scale evaluations of sweetpotato germplasm due to savings in solvent and time.

Perhaps the most important observation in this study was that chlorogenic acid and 3,5-DCQA contents were relatively high in stele tissue of two genotypes, PI 399163 and 'TIS 70357'. Previous studies (Peterson et al.2005; Son et al., 1991; Stange et al., 2001) indicated that the compounds occur at high levels only in the outer tissue of storage roots or in the inner tissue of very small storage roots (Padda and Picha, 2007a). The stele comprises most of the mass of market-sized sweetpotatoes, and increasing stele phytonutrient content would be required to substantially improve the nutritional quality of sweetpotatoes as they are typically consumed in the United States. The highest content of 3,5-DCQA found in sweetpotato leaves (Islam et al., 2002) is over eight times the highest stele content found in this study. However, the dietary contribution at the highest stele level would be substantial where sweetpotato roots are a staple food. At present, we are unaware of any recommended dietary intake for these compounds. Increasing the content of these compounds in sweetpotato stele may be undesirable due to the association of phenolic acid compounds with browning (Walter and Schadel, 1981). The degree of variation found in our small sampling of sweetpotato genotypes indicates that screening of an extensive sweetpotato germplasm collection would probably result in the discovery of sweetpotato genotypes with even higher contents.

Table 4. Growth ratings for eight bacteria grown in untreated medium (Co.) and medium containing caffeic acid, chlorogenic acid, and three isomers of dicaffeoyl quinic acid (DCQA) at $1000 \mu \mathrm{g} \cdot \mathrm{mL}^{-1}(\mathrm{Tr}$.$) .$

\begin{tabular}{|c|c|c|c|c|c|c|c|c|c|c|}
\hline \multirow[b]{3}{*}{ Bacterium $^{z}$} & \multicolumn{2}{|c|}{ 4,5-DCQA } & \multicolumn{2}{|c|}{ 3,5-DCQA } & \multicolumn{2}{|c|}{ 3,4-DCQA } & \multicolumn{2}{|c|}{ Caffeic acid } & \multicolumn{2}{|c|}{ Chlorogenic acid } \\
\hline & Co. & Tr. & Co. & Tr. & Co. & Tr. & Co. & Tr. & Co. & Tr. \\
\hline & & & & & Growth $\mathrm{rc}$ & 0 ( & & & & ---------- \\
\hline Acc & $2.0 \pm 0.0$ & $2.0 \pm 0.0$ & $2.0 \pm 0.0$ & $2.0 \pm 0.0$ & $3.0 \pm 0.0$ & $2.0 \pm 0.0$ & $1.8 \pm 1.0$ & $3.0 \pm 0.0$ & $3.0 \pm 0.0$ & $3.0 \pm 0.0$ \\
\hline $\mathrm{Pp}$ & $3.0 \pm 0.0$ & $3.0 \pm 0.0$ & $3.0 \pm 0.0$ & $3.0 \pm 0.0$ & $3.0 \pm 0.0$ & $3.0 \pm 0.0$ & $3.0 \pm 0.0$ & $3.0 \pm 0.0$ & $3.0 \pm 0.0$ & $3.0 \pm 0.0$ \\
\hline Psm & $3.0 \pm 0.0$ & $2.8 \pm 0.5$ & $2.0 \pm 0.0$ & $2.0 \pm 0.0$ & $3.0 \pm 0.0$ & $3.0 \pm 0.0$ & $3.0 \pm 0.0$ & $3.0 \pm 0.0$ & $3.0 \pm 0.0$ & $3.0 \pm 0.0$ \\
\hline Pst & $3.0 \pm 0.0$ & $3.0 \pm 0.0$ & $3.0 \pm 0.0$ & $3.0 \pm 0.0$ & $2.5 \pm 0.6$ & $1.0 \pm 0.0$ & $2.5 \pm 0.6$ & $2.8 \pm 0.5$ & $3.0 \pm 0.0$ & $1.3 \pm 0.0$ \\
\hline Rs & $1.3 \pm 0.5$ & $0.0 \pm 0.0$ & $1.3 \pm 0.5$ & $0.5 \pm 0.6$ & $1.0 \pm 0.0$ & $0.0 \pm 0.0$ & $2.0 \pm 0.0$ & $2.0 \pm 0.0$ & $3.0 \pm 0.0$ & $1.3 \pm 0.5$ \\
\hline $\mathrm{Xc}$ & $3.0 \pm 0.0$ & $2.8 \pm 0.5$ & $3.0 \pm 0.0$ & $2.8 \pm 0.5$ & $3.0 \pm 0.0$ & $2.3 \pm 1.0$ & $3.0 \pm 0.0$ & $3.0 \pm 0.0$ & $3.0 \pm 0.0$ & $3.0 \pm 0.0$ \\
\hline
\end{tabular}

${ }^{\mathrm{z}} \mathrm{Aac}=$ Acidovorax avenae $\mathrm{ssp}$. citrulli, $\mathrm{Ec}=$ Erwinia chrysanthemi, $\mathrm{Pp}=$ Pseudomonas putida. Psm $=$ Pseudomonas syringae pv. maculicola, $\mathrm{Pst}=$ Pseudomonas syringae $\mathrm{pv}$. tomato, $\mathrm{Ps}=$ Pseudomonas synxantha, $\mathrm{Rs}=$ Ralstonia solanacearum, $\mathrm{Xc}=$ Xanthomonas campestris.

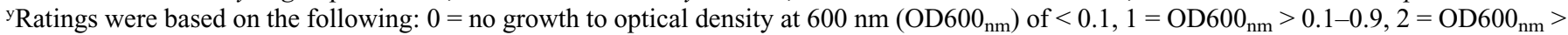
$0.9-1.9,3=\mathrm{OD}^{2} 00_{\mathrm{nm}}>1.9$. 


\section{Literature Cited}

Beninger, C.W., M.M. Abou-Zaid, A.L.E. Kistner, R.H. Hallett, M.J. Igbal, B. Grodzinsky, and J.C. Hall. 2004. A flavone and two phenolic acids from Chysanthemum morifolium with phytotoxic and insect growth regulating activity. J. Chem. Ecol. 30:589-606.

Chuda, Y., H. Ono, M. Ohnishi-Kameyama, T. Nagata, and T. Tsushida. 1996. Structural identification of two antioxidant quinic acid derivatives from garland (Chrysanthemum coronarium L.). J. Agr. Food Chem. 44:2037-2039.

Clark, C.A. and J.W. Moyer. 1988. Compendium of sweetpotato diseases. APS Press, St. Paul, MN.

Clifford, M.N. 2000. Chlorogenic acid and other cinnamates: Nature, occurrence, dietary burden, absorption and metabolism. J. Sci. Food Agr. 80:1033-1043.

Clifford, M.N., S. Knight, and N. Kuhnert. 2005. Discriminating between the six isomers of dicaffeoylquinic acid by LC-MS ${ }^{n}$. J. Agr. Food Chem. 53:3821-3832.

Cuppels, D.A. and T. Ainsworth. 1995. Molecular and physiological characterization of Pseudomonas syringae pv. tomato and Pseudomonas syringae pv. maculicola strains that produce the phytotoxin coronatine. Appl. Environ. Microbiol. 61:3530-3536.

Dowd, P.F. and F.E. Vega. 1996. Enzymatic oxidation of allelochemicals as a basis for resistance against insects: effects on the cornleaf hopper Dalbulus maidis. Nat. Toxins 4:85-91.

Ellis, P.R. 1998. Exploiting the resistance in carrots and wild umbelliferae to the carrot fly Psila rosae (F.). Presentation IOBC/ Eucarpia Workshop Meeting, Dundee, Scotland, 14-17 Sept., 1998. Farkas, G.L. and Z. Kiraly. 1962. Phenolic compounds in the physiology of plant diseases and disease resistance. Phytopathologische Zeitschrift 44:105-150.

Faulds, C.B. and G. Williamson. 1999. The role of hydroxycinnamates in the plant cell wall. J. Sci. Food Agr. 79:393-395.

Frey-Wyssling, A. and S. Babler. 1957. Biochemistry of greenhouse tobacco. Naturwissenschaften 13:399-400.

Guan, Y., T. Wu, M. Lin, and J. Ye. 2006. Determination of pharmacologically active ingredients of sweetpotato (Ipomoea batatas L.) by capillary electrophoresis with electrochemical detection. J. Agr. Food Chem. 54:24-28.

Harrison, H.F., J.K. Peterson, D.M. Jackson, and M.E. Snook. 2005. Periderm resin glycoside contents of sweetpotato, Ipomoea batatas (L.) Lam. clones and their biological activities. Allelopathy J. 12:53-60.

Harrison, H.F., J.K. Peterson, and M.E. Snook. 2006. Simulated drought induces high caffeic acid contents in storage root periderms of greenhouse grown sweetpotatoes. HortScience 41:277278.

Harrison, H.F., J.K. Peterson, M.E. Snook, J.R. Bohac, and D.M. Jackson. 2003. Quantity and potential biological activity of caffeic acid in sweet potato storage root periderm. J. Agr. Food Chem. 51:2943-2948.

Hendson, M., D.C. Hildebrand, and M.N. Schroth. 1992. Relatedness of Pseudomonas syringae pv. tomato, Pseudomonas syringae pv. maculicola and Pseudomonas syringae pv. antirrhini. J. Appl. Bacteriol. 73:455-464.

Horak, M.J. and L.M. Wax. 1991. Growth and development of bigroot morning glory (Ipomoea pandurata). Weed Sci. 5:805-810.

Hung, C.L. and R.A. Rhode. 1973. Phenol accumulation related to resistance in tomato to infection by rootknot and lesion nematodes. J. Nematol. 5:253-258.

Islam, M.S., M. Yoshimoto, S. Yahara, S. Okuno, K. Ishiguro, and O. Yamakawa. 2002. Identification and characterization of foliar polyphenolic composition in sweetpotato (Ipomoea batatas L.) genotypes. J. Agr. Food Chem. 50:3718-3722.

Johnson, G. and L.A. Schaal. 1952. Relationship of chlorogenic acid to scab resistance in potatoes. Science 115:627-629.

Kimura, Y., H. Okuda, T. Hatano, I. Agata, and S. Arichi. 1984. Studies on the activities of tannins and related compounds: V.
Inhibitory effects on lipid peroxidation in mitochondria and microsomes of liver. Planta Med. 50:473-477.

King, E.O., M.K. Ward, and D.E. Raney. 1954. Two simple media for the demonstration of pyocyanin and fluorescein. J. Lab. Clin. Med. 44:301-307.

Knypl, J.S. and K.M. Janas. 1976. Is decreased activity of nitrate reductase in roots of carrot infested with northern rootknot nematode related to the increased level of chlorogenic acid? Biochem. Physiol. Pflanz. 169:607-615.

Kojima, M. and T. Kondo. 1985. An enzyme in sweetpotato that catalyzes the conversion of chlorogenic acid, 3-caffeoylquinic acid, to 3,5-dicaffeoylquinic acid. Agr. Biol. Chem. 49:2467-2469.

Kuć, R.E., R.E. Henze, A.J. Ullstrup, and F.W. Quackenbush. 1956. Chlorogenic and caffeic acids as fungistatic agents produced by potatoes in response to inoculation with Helminthosporum carbonum. J. Amer. Chem. Soc. 78:3123-3125.

Lott, H.V. 1960. The effect of light of short wavelength on the biosynthesis of polyphenols in plants. Planta 55:480-495.

Mote, U.N. and D.R. Dasgupta. 1979. Significance of phenylalanine ammonia lyase in resistance response of tomato to the rootknot nematode. J. Nematol. 9:66-68.

Murata, Y., J.R. Kawabata, and R. Niki. 1995. Anti-oxidative caffeoylquinic acid derivatives in the roots of burdock (Arctium lappa L.). J. Agr. Food Chem. 43:2592-2595.

Nicholson, R.L. and R. Hammerschmidt. 1992. Phenolic compounds and their role in disease resistance. Annu. Rev. Phytopathol. 30:369-389.

Padda, M.S. and D.H. Picha. 2007a. Antioxidant activity and phenolic composition in 'Beauregard' sweetpotato are affected by root size and leaf age. J. Amer. Soc. Hort. Sci. 132:447-451.

Padda, M.S. and D.H. Picha. 2007b. Methodology optimization for quantification of total phenolics and individual phenolic acids in sweetpotato (Ipomoea batatas L.) roots. J. Food Sci. 72:C412-C416.

Peluso, G., V. De Feo, F. De Simone, E. Bresciano, and M.L. Vuotto. 1995. Studies on the inhibitory effects of caffeoylquinic acid on monocyte migration and superoxide ion production. J. Nat. Prod. 58:639-646.

Peterson, J.K., H.F. Harrison, M.E. Snook, and D.M. Jackson. 2005. Chlorogenic acid content in sweetpotato germplasm: Possible role in disease and pest resistance. Allelopathy J. 16:239-250.

Robards, K., P.D. Prenzler, G. Tucker, P. Swatsitang, and W. Glover. 1999. Phenolic compounds and their role in oxidative processes in fruits. Food Chem. 66:401-436.

Robinson, E.W., M. Cordeiro, S. Abdel-Malek, Q. Jia, S.A. Chow, M.G. Reinecke, and W.M. Mitchell. 1996a. Dicaffeoylquinic acid inhibitors of human immunodeficiency virus integrase: Inhibition of the core catalytic domain of human immunodeficiency virus integrase. Mol. Pharmacol. 50:846-855.

Robinson, E.W., M.G. Reinecke, S. Abdel-Makek, Q. Jia, and S.A. Chow. 1996b. Inhibitors of HIV-1 replication that inhibit HIV integrase. Proc. Natl. Acad. Sci. USA 93:6326-6331.

Rudkin, G.O. and J.M. Nelson. 1947. Chlorogenic acid and respiration in sweetpotato. J. Amer. Soc. Chem. 69:1470.

Shimozono, H., M. Kobori, H. Shinmoto, and T. Tsushida. 1996. Suppression of mouse melanoma B16 cells by sweetpotato extract. Nippon Shokuhin Kogaku Kaishi 43:313-317.

Son, K.-C., R.R. Severson, M.E. Snook, and S.J. Kays. 1991. Root carbohydrate, organic acid and phenolic chemistry in relation to sweetpotato weevil resistance. HortScience 26:1305-1308.

Stange R.R., Jr., S.L. Midland, G.J. Holmes, J.J. Sims, and R.T. Mayer. 2001. Constituents from the periderm and outer cortex of Ipomoea batatas with antifungal activity against Rhizopus stolonifer. Postharvest Biol. Technol. 23:85-92.

Steinbauer, C.E. and L.J. Kushman. 1971. Sweet potato culture and diseases. U.S. Dept. Agr., Agr. Res. Serv., Agr. Hdbk. No. 388.

Summers, C.B. and G.W. Felton. 1994. Prooxidant effects of phenolic acids on the generalist herbivore Helicoverpa zea (Lepidoptera: Noctuidae): Potential mode of action for phenolic compounds in plant anti-herbivore chemistry. Insect Biochem. Mol. Biol. 24:943-953. 
Takenaka, M., X. Yan, H. Ono, M. Yoshida, T. Nagata, and T. Nakanishi. 2003. Caffeic acid derivatives in the root of yacon (Smallanthus sonchifolius). J. Agr. Food Chem. 51:793-796.

Teramachi, F., T. Koayamo, T. Kowithayakorn, M. Hayshi, K. Komiyama, and M. Ishibashi. 2005. Collagenase inhibitory quinic acid esters from Ipomea pes-caprae. J. Nat. Prod. 68:794-796.

Truong, V.-D., R.F. McFeeters, R.T. Thompson, L.L. Dean, and B. Shofran. 2007. Phenolic acid content and composition in leaves and roots of common commercial sweetpotato (Ipomoea batatas L.) cultivars in the United States. J. Food Sci. 72:C343-C349.

Trute, A., J. Gross, F. Mutschler, and A. Nahrstedt. 1997. In vitro antispasmodic compounds of the dry extract obtained from Hedera helix. Planta Med. 63:125-129.

Uritani, I. and M. Miyano. 1955. Derivatives of caffeic acid in sweet potato attacked by black rot. Nature 175:812.
Uritani, I., M. Uritani, and H. Yamada. 1960. Similar metabolic changes induced in sweetpotato by poisonous chemicals and by Ceratostomella fimbriata. Phytopathology 50:30-34.

Walter, W.M. and W.E. Schadel. 1981. Distribution of phenols in 'Jewel' sweetpotato [Ipomoea batatas (L.) Lam.] roots. J. Agr. Food Chem. 29:904-906.

Wojcicki, J. 1978. Effect of 1,5 dicaffeoylquinic acid (cynarine) on cholesterol levels in serum and liver of acute ethanol treated rats. Drug Alcohol Depend. 3:143-145.

Zhu, K., M.L. Coreiro, J. Atienza, W.E. Robinson, Jr., and S.A. Chow. 1999. Irreversible inhibition of human immunodeficiency virus type 1 integrase by dicaffeoylquinic acids. J. Virol. 73:3309-3316.

Zhu, X., H. Zhang, and R. Lo. 2004. Phenolic compounds from the leaf extract of artichoke (Cynara scolymus L.) and their antimicrobial activities. J. Agr. Food Chem. 52:7272-7278. 